\title{
ENHANCEMENT OF THE 3D SEISMIC INTERPRETATION BY USING SEISMIC ATTRIBUTES AT THE SOUTHERN REGION OF WEST ELQANTARA, NILE DELTA, EGYPT
}

\author{
El Motany, A. ${ }^{1}$ Helal, A. ${ }^{2}$ and Farag, K. S. I. ${ }^{2}$ \\ ${ }^{1}$ Consultant Geophysicist, Cairo, Egypt \\ ${ }^{2}$ Geophysics Department, Faculty of Science, Ain Shams University, Cairo, Egypt
}

\begin{abstract}
The main target of the present study is to identify the structure and the stratigraphic features associated with the potential traps by using the recent acquired 3D seismic data at the southern part of West El Qantara area in the Nile Delta Basin. The integrated usage of seismic attributes (Variance, Root Mean Square RMS and Amplitude Extraction) added significant information on the geological features, facies and the minor structures of the study area and consequently enhanced the hydrocarbon potentiality. The correlation of extracted depositional and structure models from the interpreted seismic data with the regional stratigraphic and structural setting of the Nile Delta showed a good match and led to a better understanding of the geological history and hydrocarbon potentiality of the study area. This consequently could be used as useful tool for future development in the study area.
\end{abstract}

Keywords: 3D Seismic Interpretation, 3D Seismic Attributes, Variance, Amplitude Extraction, West El Qantara, Egypt.

\section{INTRODUCTION}

The Nile Delta Basin is the most significant gas source province in Egypt and one of the most promising areas for future petroleum exploration in North-eastern Africa. The Delta begins approximately $20 \mathrm{Km}$ north of Cairo and extends to the North about $150 \mathrm{~km}$. At the cost of the Mediterranean Sea, it extends about $250 \mathrm{~km}$ from Alexandria in the West to Port Said in the East. In 2008 Dana Gas Egypt started an aggressive drilling campaign in West El Qantara block (WQ) onshore of the Nile Delta basin to test the attractive exploration potential; they achieved a remarkable success of gas discoveries (Fig.1a).

In Southern Part of WQ, they drilled their first discovery Sama-1well in the study area which were covered at this time by 2D seismic, the discovery tested at $13 \mathrm{MM} \mathrm{scf} / \mathrm{d}$ of dry gas from a reservoir of Miocene age. The estimated reserves for this discovery are about 48 bcf gas. This induced the company to acquire 3D seismic over the Southern WQ area to identify the possible remaining traps. Two wells were drilled based on the 3D seismic interpretation; NW Sama-1 well is a discovery at the Miocene age, while Fressia-1 well is dry well.

Seismic attributes are the components of the seismic data which are obtained qualitatively or quantitatively from the seismic data. Seismic Attributes were introduced as a part of the seismic interpretation in early 1970's. Since then, many new attributes were introduced to be computed. In reflection seismology, a seismic attribute is a quantity extracted or derived from seismic data that can be analyzed in order to enhance information that might be more subtle in a traditional seismic image. This enabled a better geological or geophysical interpretation of the data. Examples of seismic attributes can include measured time, amplitude, RMS, variance, frequency and attenuation as well as a combination of all of these (Adero et al., 2017).

The authors in the current research used the seismic attributes of the local horizons, interval attributes and frequency attributes to add details on the geological features, facies and the minor structures of the study area. These details hardly can be seen with regular seismic interpretation process and consequently will enhance the hydrocarbon potentiality exploration and development in targeted fields. The higher correlation factor 
El Motany, et al.

between the extracted depositional and structure models from the interpreted seismic data with the regional stratigraphic and structural settings of the Nile Delta basin gives the reliability to the current work.

\section{GENERAL GEOLOGIC SETTING OF THE AREA}

The study area lies on the northern part of the Nile Delta basin which in turn is located in the northern part of Egypt. The Nile Delta covers an onshore area about $25,000 \mathrm{~km}^{2}$ and it is offshore area about $35,000 \mathrm{~km}^{2}$ (Khalf, 2016). Nile Delta basin was the target of interest of too many scientists. Said, (1990) and Sestini, (1989) stated that the Nile Delta basin was affected by the complex evolution of the African, Eurasian and Arabian plates. The study area is situated at the South West of El Qantara in the northern part the Nile Delta basin of Egypt. The study area located between latitudes $30^{\circ} 54^{\prime} 00^{\prime \prime}$ and $31^{\circ} 00^{\prime} 00^{\prime \prime} \mathrm{N}$ and longitudes $31^{\circ} 46^{\prime} 00^{\prime \prime}$ and $32^{\circ} 09^{\prime} 00^{\prime \prime}$ E, Fig. (1b).

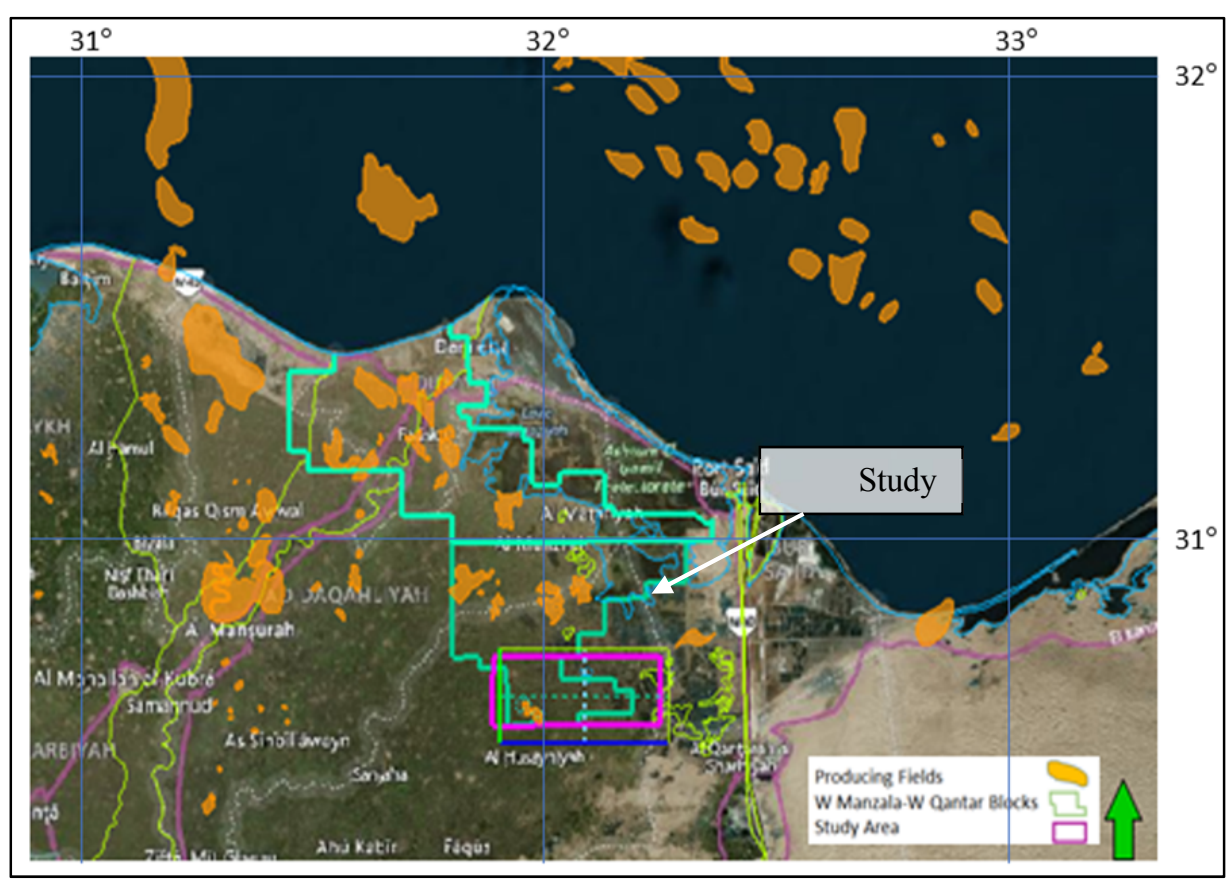

(a)

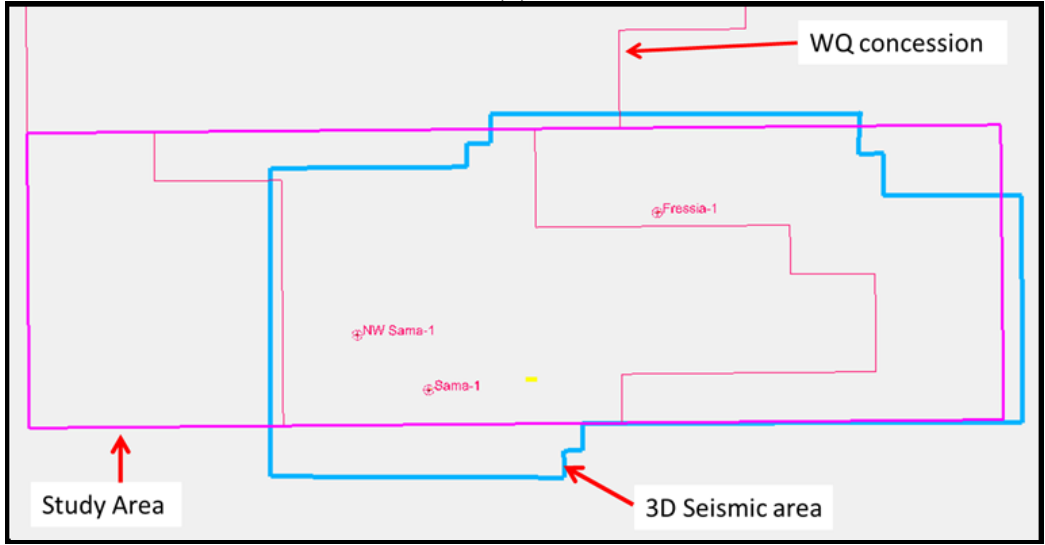

(b)

Fig. 1: a) Satellite image of the north eastern part of Nile Delta showing the study area; b) The location map of the study area.

The most striking feature in the Nile Delta region is the prograding succession of Pliocene-Pleistocene age. After the earliest Pliocene transgression, the sedimentation rate kept the pace with strong tectonic subsidence for the basin and a thick progression wedge was deposited (Said, 1990). The generalized stratigraphic section is shown in Fig. 2. 
Enhancement of the 3D seismic interpretation by using seismic attributes

The Nile Delta section composed of three sedimentary cycles: 1) the Miocene cycle, whose base is rarely recorded in the delta region. It largely comprises non-marine to shallow marine deposits of the Sidi Salim, Qawasim and Abu Madi Formations. 2) Pliocene-Pleistocene cycle which includes the open marine Kafr El Sheikh Formation and the deltaic El Wastani, Mit Ghamr as well as Bilqas Formations. 3) Holocene cycle which comprises the top. Based on geophysical studies, (Sherief, 1972) reported that the depth of the basement rocks is more than $1800 \mathrm{~m}$ at the southern part of the Nile Delta and increases northward into more than $7600 \mathrm{~m}$.

Fig. 2: The generalized stratigraphy of the Nile Delta, after (El-Heiny and Morsi, 1992).

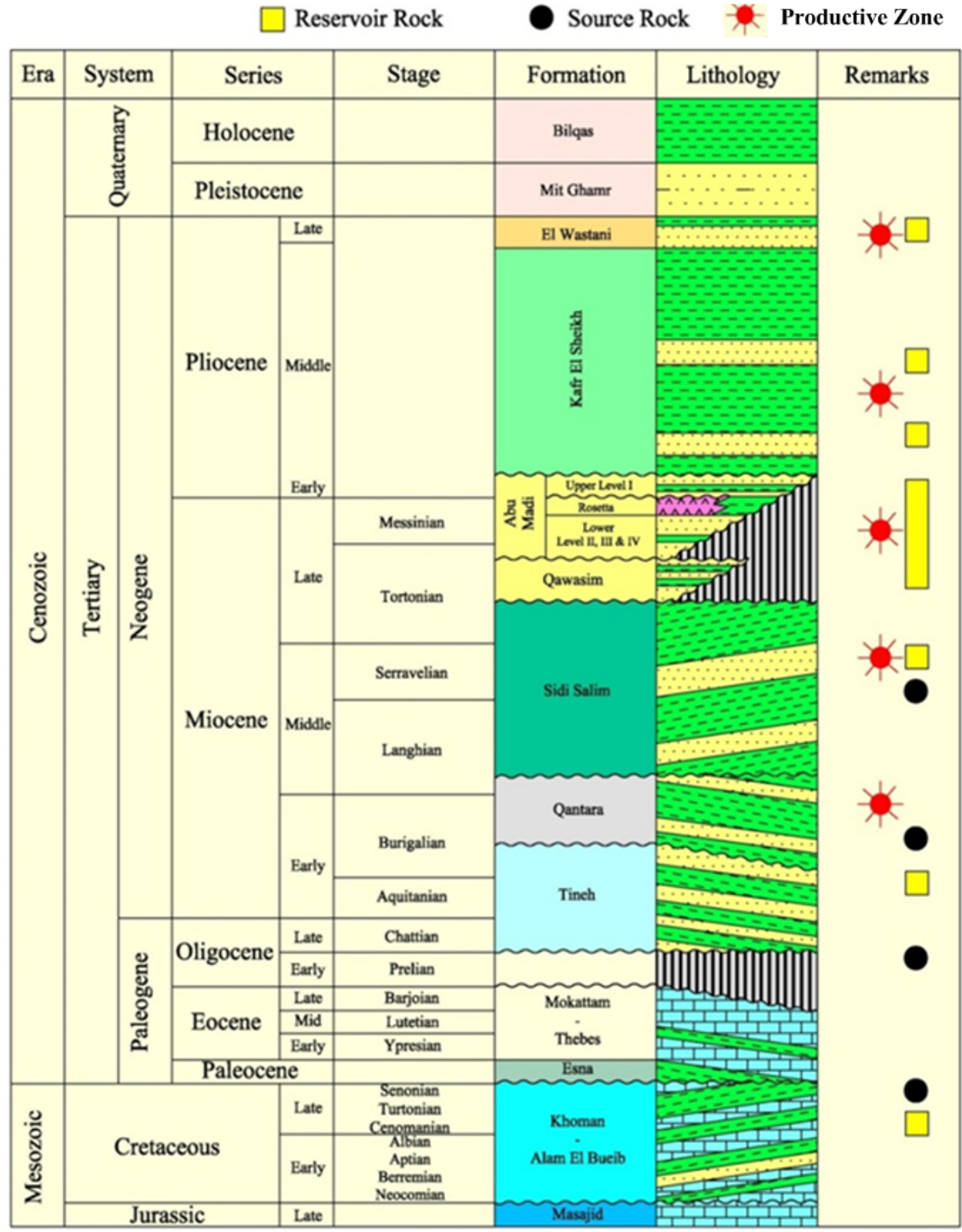

The Nile Delta Basin is a gas and condensate province, with only small amounts of oil, Fig. 3. Reservoirs in the Nile delta can be classified according to depth into three types. The first type is the shallow reservoirs (800-2700m); they are represented by high quality Pliocene reservoirs (Kafer El Sheikh and El Wastani formations). The second is the intermediate reservoirs (2700-4000m); they include Upper Miocene reservoirs of the Abu Madi and Qawasim formations and The Middle to Upper Miocene Sidi Salim Formation. The third type is the deep reservoirs (4000-6500m); they are include the Lower to Middle Miocene Qantara Formation and the Oligocene Tineh Formation (EGAS, 2015).

The main structural trends of the Nile delta were postulated by (Sestini, 1995) as follows:

1. The E-W trend which could be related to the original continental margin rifting of the south eastern Mediterranean during the early Mesozoic and probably older. The best known examples for this trend are the Oligo-Miocene Hinge Zone. 
El Motany, et al.

2. The Rosetta trend, a NE-SW trend of Late Cretaceous age is exemplified by the Pelusium, Qattara Eratothenes, and the Gamasa, Idfina and Port Said-Hout lines. In addition to the vertical motion component of these faults, they exhibit sinistral strikeslip displacement.

3. The NW-SE trend, active during the Miocene. An example of that trend is Temsah fault.

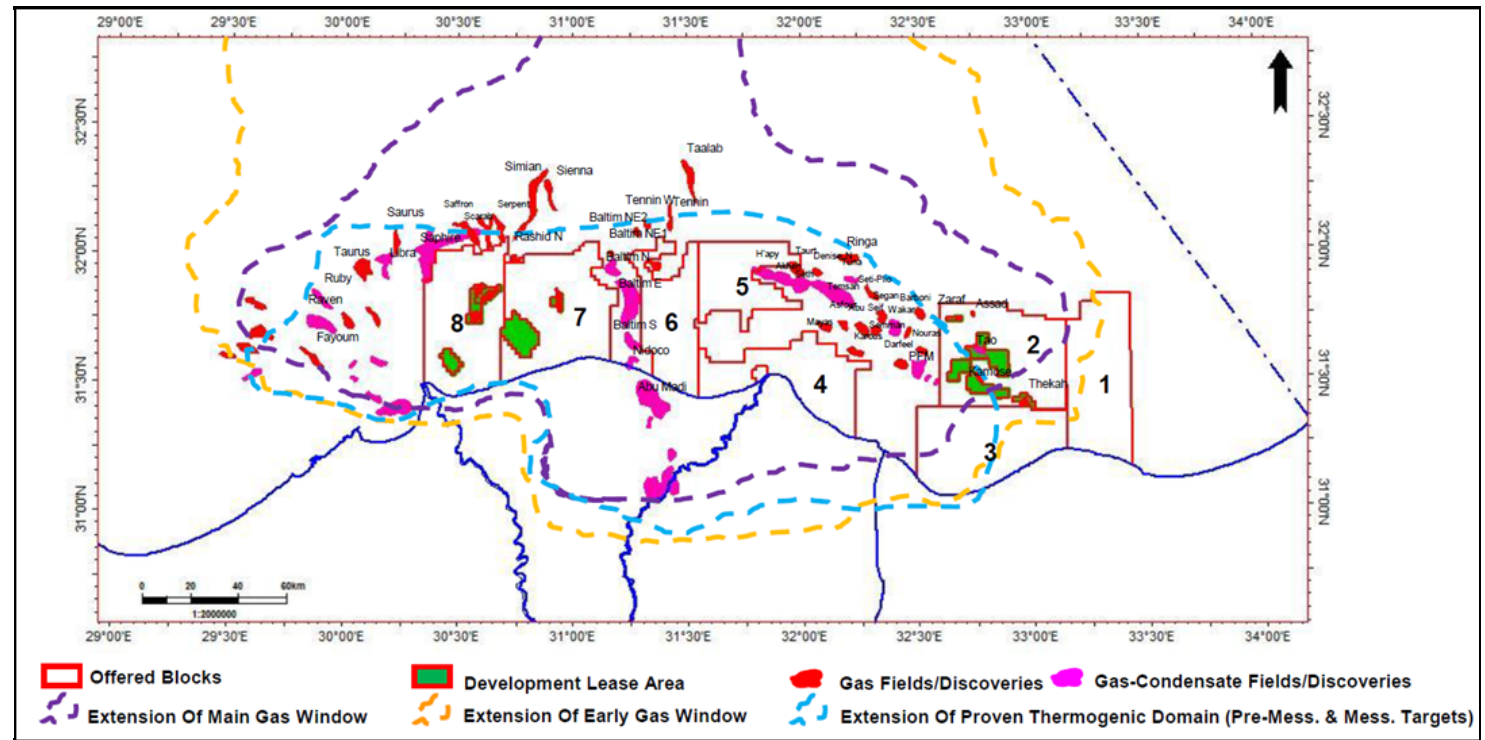

Fig. 3: The Nile Delta source rocks, after (EGAS, 2015).

The greater Nile Delta area comprises four main sub-areas as shown in Fig. (4). These sub-areas are: (1) South Delta Block, which is the southernmost part; (2) North Delta Basin (or Province) which covers much of the present day delta-front and offshore areas; it is the primary hydrocarbon-productive area; (3) The Nile Cone, which is the deep-water area of thick virtually undeformed Plio-Pleistocene sediments to the northeast; and (4) Levant Platform, a relatively stable region of thinner, deep-water pro-delta sediments. The North Delta Basin is bounded by the Faulted Flexure or Hinge Line.

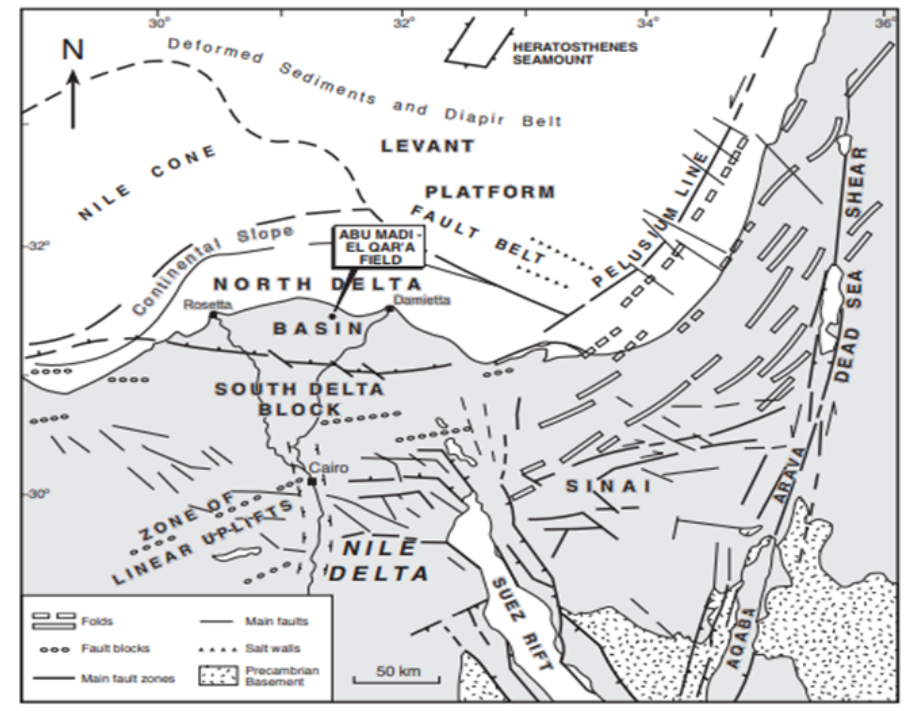

Fig. 4: Main tectonic features of the Nile Delta, Sinai and southeast Mediterranean region, after (Sestini, 1989).

The Hinge Line as shown in Fig. 4 is a W-E belt of growth faults which throw to the North by about $5000-7000 \mathrm{~m}$. The Tertiary is at least 4,500-6,000 m thick to the north of this line and 455- $1500 \mathrm{~m}$ thick to the south, in the South Delta Block. The pre-Oligocene structures are East to NNE-trending tilted faultblocks and horsts formed by repeated uplift from the Senonian to Early Eocene (Sestini, 1989).The Hinge Line corresponds to a major facies boundary in the Jurassic-Cretaceous between platform and the slope of carbonates. 
Enhancement of the 3D seismic interpretation by using seismic attributes

\section{SEISMIC INTERPRETATION}

The interpretation of seismic reflections is the process of transforming the physical responses displayed by the seismic sections into geological information concerning either structural or stratigraphic features (Badely, 1985).

\section{Well to Seismic Tie (Synthetic Seismogram).}

Tying well data to seismic is a process helping to detect seismic reflections that correspond to geological formations. Seismic interpreters usually establish a forward model to predict the seismic response of the subsurface strata. This model is a direct one dimensional model of acoustic energy traveling through the layers of the Earth which is called synthetic seismogram. The synthetic seismogram is generated by convolving the Reflection Coefficient ( $\mathrm{RC}$ ) values derived from the digitized sonic and density logs with the wavelet derived from the seismic data (Lindseth, 1979).

A synthetic seismogram was created for Sama-1 well as a stratigraphic-control, the only well which has a complete set of logs, Fig. (5). The sonic log edited and calibrated with the check shot, and multiplied by the edited density log to obtain the Acoustic Impedance (AI), then calculating the Reflection Coefficient (RC) between layers, which convolved with the extracted wavelet from the 3D PSTM seismic to generate the synthetic.

The acoustic impedance (AI) can be calculated from the following equation (Sheriff and Geldart, 1982):

$$
\mathrm{AI}=\operatorname{velocity}(\mathrm{V}) * \text { density }(\rho)
$$

where,

$\mathrm{V}=$ The check shot velocity used for calibration;

$\rho=$ The edited recorded density $\log$

Equation (2) allows us to compute the Reflection Coefficient (RC) between layers. It represents the ratio of amplitude of the reflected wave to the incident one (Sheriff and Geldart, 1982):

$$
\mathrm{RC}=\left(\mathrm{V}_{2} \rho_{2}-\mathrm{V}_{1} \rho_{1}\right) /\left(\mathrm{V}_{2} \rho_{2}+\mathrm{V}_{1} \rho_{1}\right)
$$

where,

$\mathrm{V}_{1}=$ is the velocity of the first layer;

$\mathrm{V}_{2}=$ is the velocity of the second layer;

$\rho_{1}=$ is the density of the first layer;

$\rho_{2}=$ is the density of the second layer.

The resulted synthetic with correlation coefficient of 0.693 shows obvious correlation with the seismic data passing through Sama-1 well. The typical interpreted seismic section explains how the seismic data fits with both the synthetic seismogram and gamma ray logging results. The top of Abu Madi Miocene (AM) reservoir formation represented as peak (+ve) amplitude, a well match are represented for the series of reflectivity older than AM formation, Fig. (6).

The quality of the seismic data varies from good to fair in the section deeper than Abu Madi Miocene formation, while it is better quality in the shallower section. The quality of the interpreted stratigraphic horizons and geological faults was mainly controlled by the seismic data quality and depending on the working depth-level within the study area.

\section{The Identification of the Seismic Horizons.}

The process of seismic interpretation begins with the identification of the distinct seismic horizons or boundaries. These boundaries either related to a stratigraphic origin or a structural origin. The real geological data by the direct drilling through wells will be extended along the surveyed area from line to line at a line intersection enabled the interpreter to identify all the geological features or tracing a specific stratigraphic boundary. The picking of the entire survey should be tied together systematically in a closed loop to branch out covering the whole interpreted area (Badely, 1985). 
El Motany, et al.

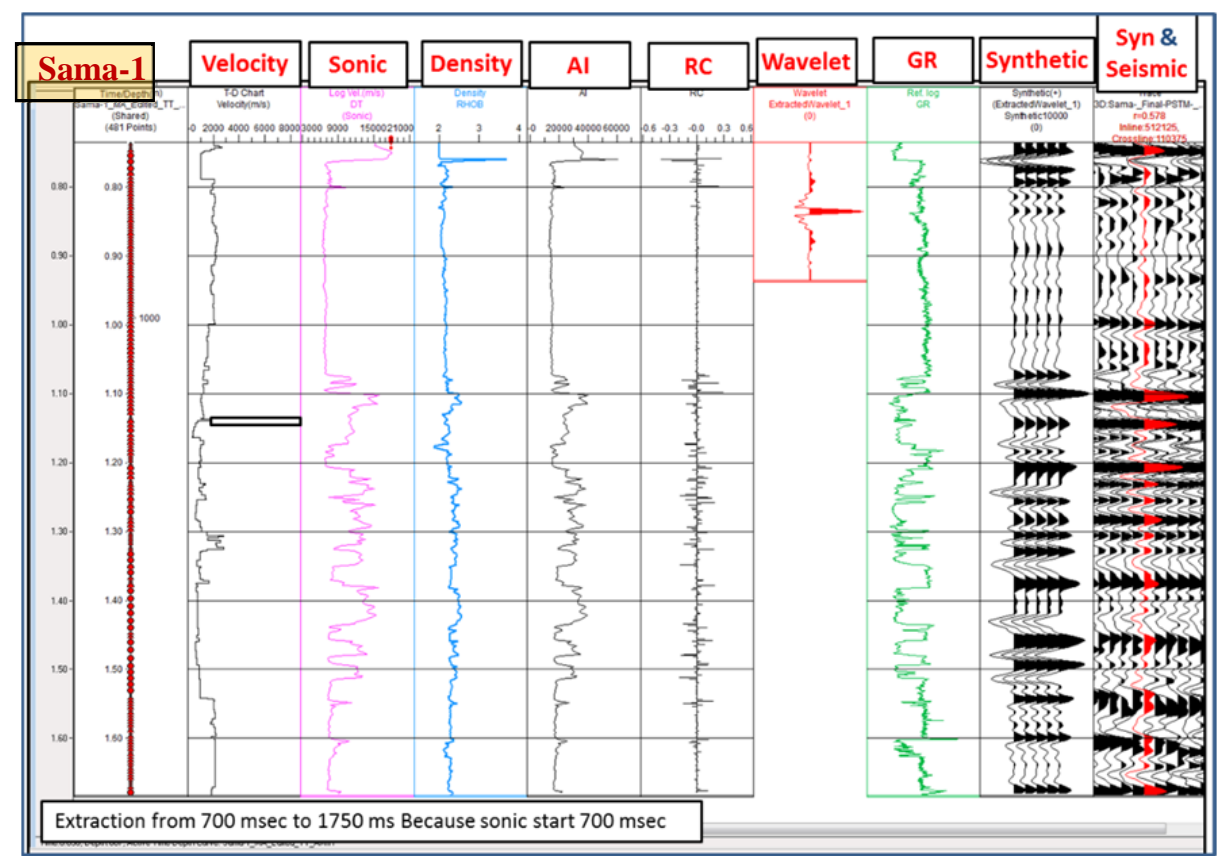

Fig. 5: Synthetic seismogram of Sama-1 well with correlation factor 0.693 .

Fig. 6: a) Basemap showing the location of the displayed EW Seismic line. b) E-W seismic line showing the seismic well tie and the synthetic seismogram at the Sama-1 well location.
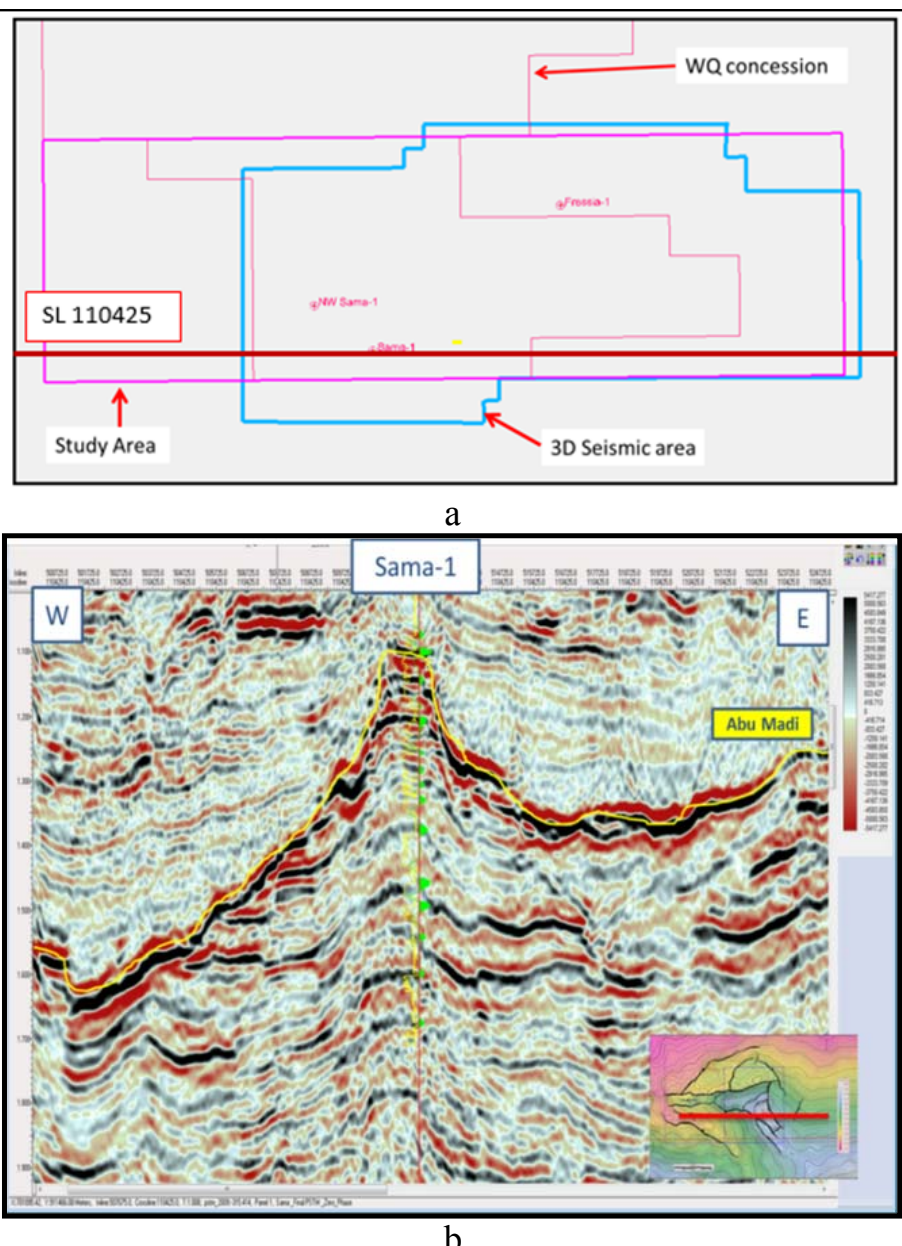

$\mathrm{b}$

Five seismic boundaries were identified distinctly and interpreted in the study area. Their corresponding ages from top to bottom are: Late Pliocene, Middle Pliocene, Late Miocene, Oligocene, and Eocene (Fig. 7). 
Enhancement of the 3D seismic interpretation by using seismic attributes

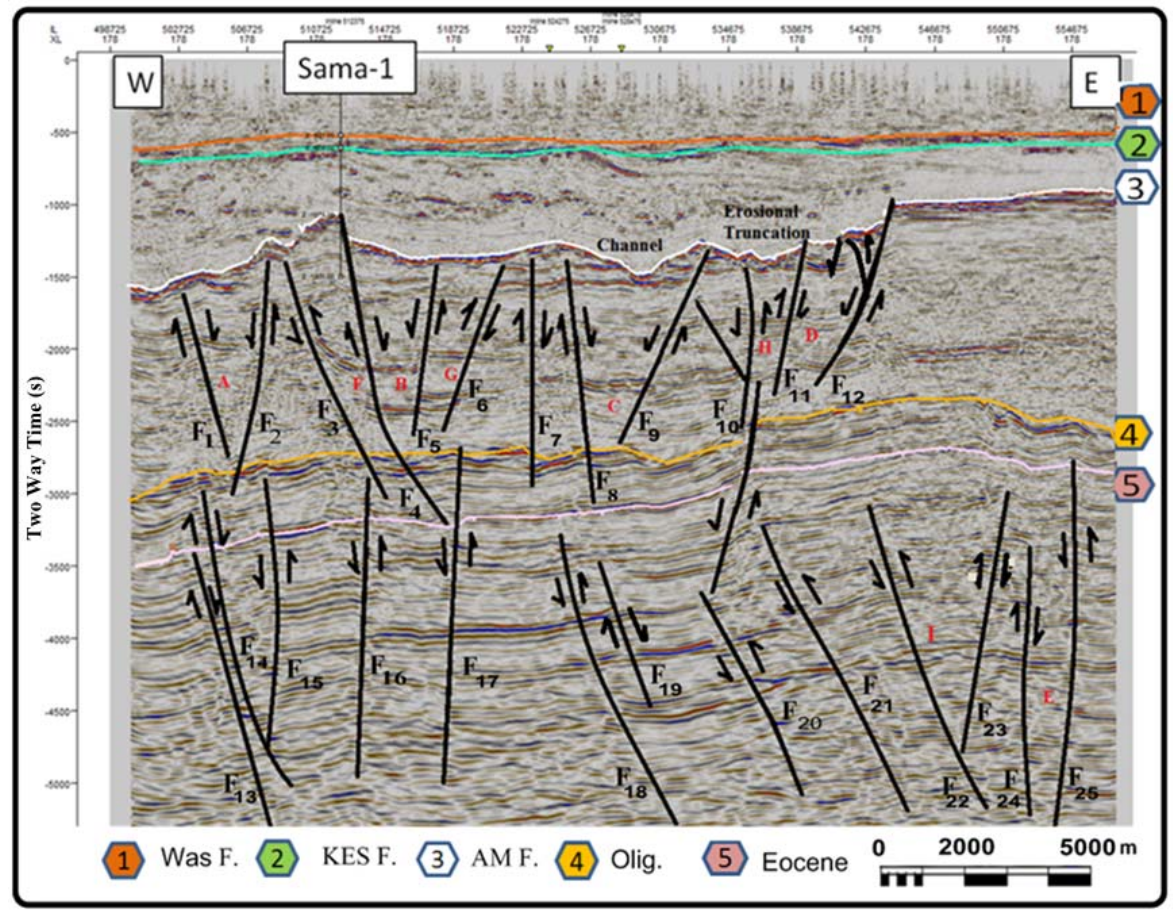

Fig. 7: The whole interpreted crossline seismic section \#178 showing the Miocene angular unconformity and the OligoceneEocene faults of the study area.

\section{The Major Structural Features}

Figure (7) depicts the interpreted crossline seismic section \# 178 passing through Sma-1 Well and extended from east to west. The normal and listric faults with rotated blocks among the Eocene and the Oligocene horizons. The section also shows a series of uplifted fault blocks (A, B, C, D, and E) and another depressed one (F, G, H, and I). The most striking feature is the Miocene unconformity (Abu Madi Formation) is characterized by basal incisions on the slope during the initiation of the low stand.

This created an intra-slope basin, which was later filled with turbidities deposits at the base overlain by further infilling of the slope basin by aggrading channel. The reservoir a slope and a base of a slope lying unconformably over an erosional surface within the intra-slope basin. This channel needs definitely the seismic attributes analysis to be studied in details.

\section{Seismic attributes}

Seismic attributes describe seismic data and are defined as quantitative derivatives of a basic seismic measurement which can be extracted along a seismic trace, a horizon surface, or summed over a time window (Brown, 1996). Seismic attributes were considered specific measurements of geometric, kinematic, dynamic, or statistical features which can be obtained from seismic data. Some of seismic attributes are more sensitive than others to specific reservoir conditions, some are better at revealing subsurface anomalies which are not easily detectable, and some have been used as direct hydrocarbon indicators (Chopra and Marfurt, 2005).

Attributes can be divided into eight categories: pre-stack attributes, post-stack attributes, instantaneous attributes, wavelet attributes, physical attributes, geometrical attributes, reflective attributes, and transmissive attributes (Taner, 2001). The evolution of seismic attributes is closely linked to advances in computer technology.

\section{Root Main Square (RMS) Attributes.}

The RMS amplitude is a computed seismic attribute, and is defined as the square root of the sum of the squared amplitudes in a data set, divided by the sample size of data within the time window desired. This attribute is used to map hydrocarbon indicators within a zone by providing a statistical measure of the magnitude of variation in amplitude throughout a dataset (Tylern, 2015). 
El Motany, et al.

Generally, the higher acoustic impedance variations associated with variations within stacked lithology will result in an increase in the RMS values. In this study, RMS amplitude values were collected above and below the various stratigraphic boundaries by a window of varied thickness (60-40). Figure (8) shows the RMS attributes map of El Wastani Formation relatively increases in the eastern part of the study area revealing thick sedimentation aggregation (multi-channel surface) and enhanced the autotracked horizon for better interpretation of line \#178 (Fig. 9).

Fig. 8: The RMS attributes slice map above the El Wastani Formation by a window of $60 \mathrm{~ms}$ in thickness showing a thick sedimentation in the eastern area.
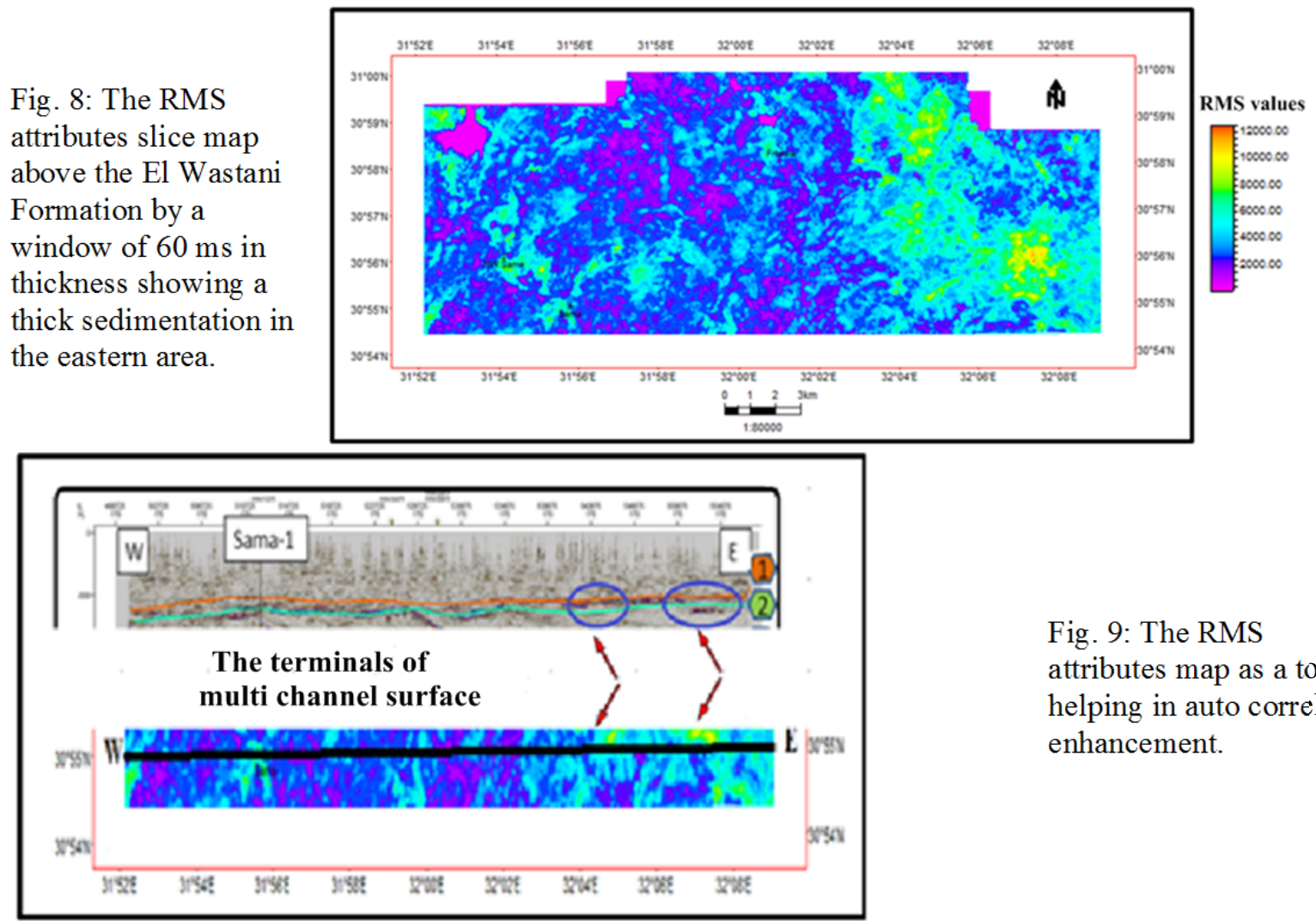

Fig. 9: The RMS attributes map as a tool helping in auto correlation enhancement.

The RMS attributes map of Kafer El Sheikh Formation as shown in Fig. (10a) displays relatively high values of RMS in the central western and southern parts bringing a lingering question in the head of the interpreter about the obtained anomaly, Fig. (10b). That anomaly is interpreted as an ancient meandering channel and could be a good hydrocarbon indicator. If this area shows low acoustic impedance, it will be a good quality reservoir or can confirm the lack of continuity of the reservoir.

By going down in depth to Abu Madi Formation (Fig. 11), the RMS attributes map adds some features which can be seen clearly such as: the confirmation of the fluvitial lithology of high RMS amplitude in the southern western parts. In addition, the presence of the channel in the southern part, coincide with the data of the seismic sections. The set of N-W faults of low amplitudes in the study area. When we reach to the Oligocene boundary (Fig. 12), the presence of the E-W fault trend and the main bodies of a group of channels disseminated in east, southern center, and in the west side of the study area.

Figure (13) describes the RMS attribute map of Eocene-Cretaceous boundary. The chaotic low RMS values and the presence of NE-SW fault trend related to the Syrian Arch System.

\section{The Variance Attributes.}

The variance attribute is an edge imaging and detection method. In probabilistic analysis, variance is the measure of how spread is the dataset around the mean value. The variance attribute uses an algorithm which computes the local variance of the input signal through a multi-trace window with the user-defined size. The algorithm of variance is innovative because it measures directly, without the need of an intermediate step (Azevedo, 2009). 
Enhancement of the 3D seismic interpretation by using seismic attributes

Fig. 10: a) The RMS attributes slice map above the Kafer El Sheikh boundary by a window of $60 \mathrm{~ms}$ in thickness; b) Meandring ancient channel was revealed by the RMS attributes map.

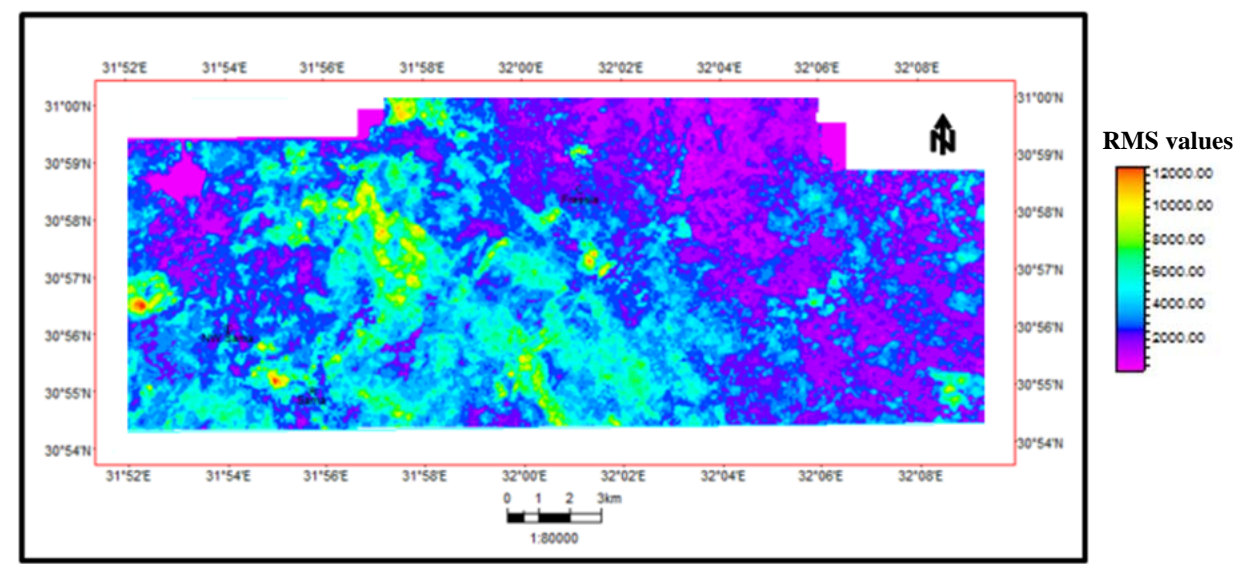

(a)

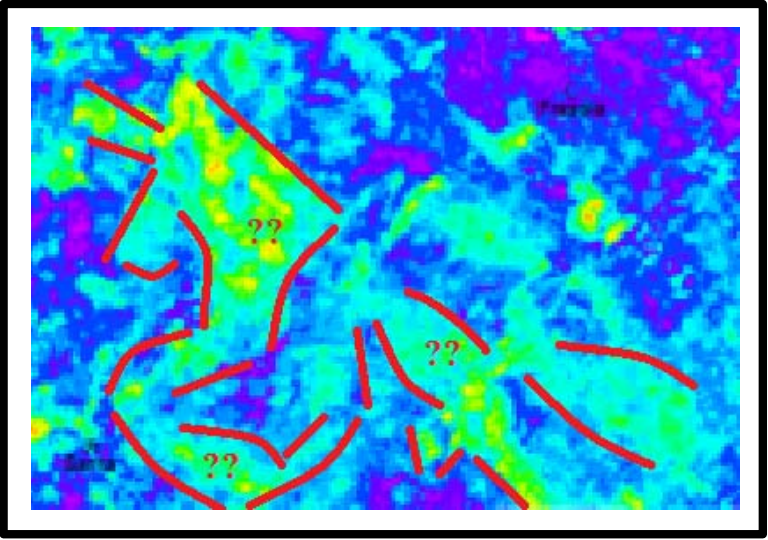

(b)

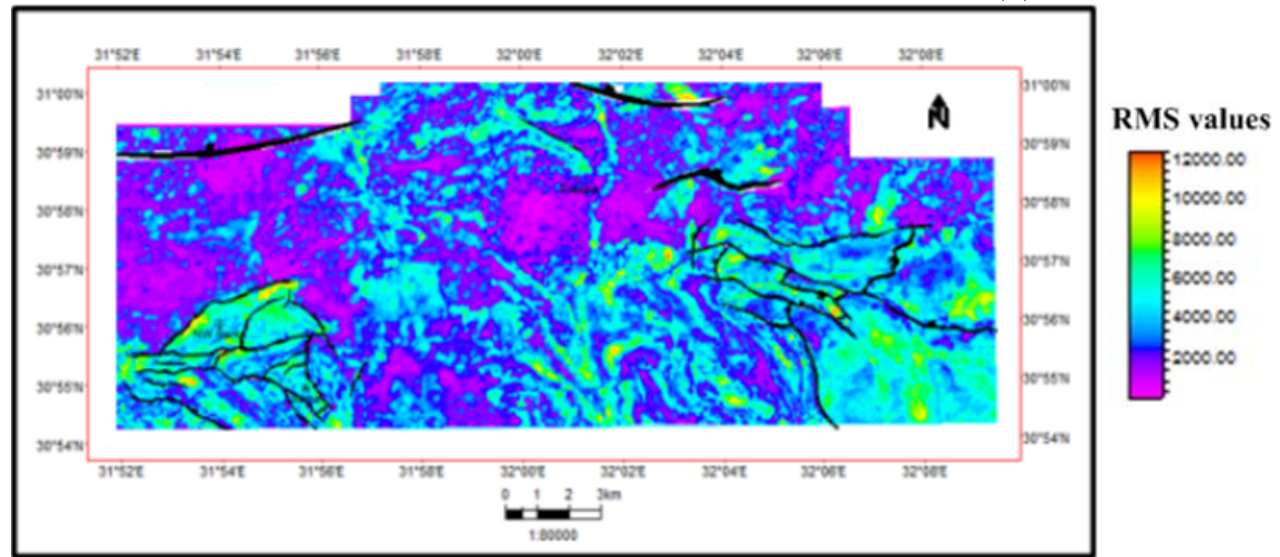

Fig. 11: The RMS attributes slice map above the Abu Madi Formation by a window of $60 \mathrm{~ms}$ in thickness showing the appearance of the multi-channel depositional feature .

Fig. 12: The RMS attributes slice map above the Oligocene boundary and below by a window of 40 $\mathrm{ms}$ in thickness showing the trapped sediments in the central part of the area.

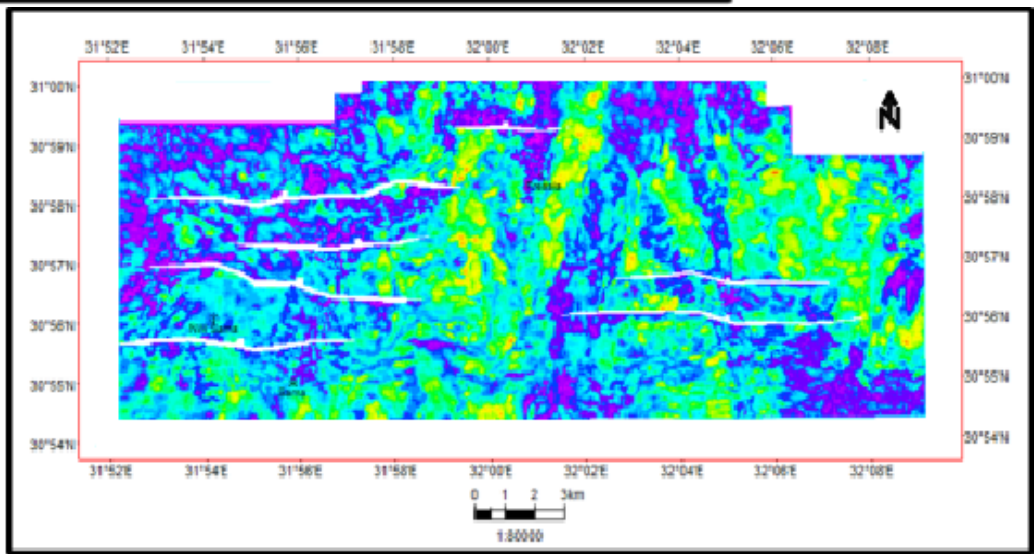

RMS values

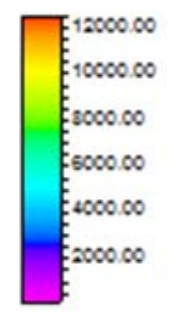




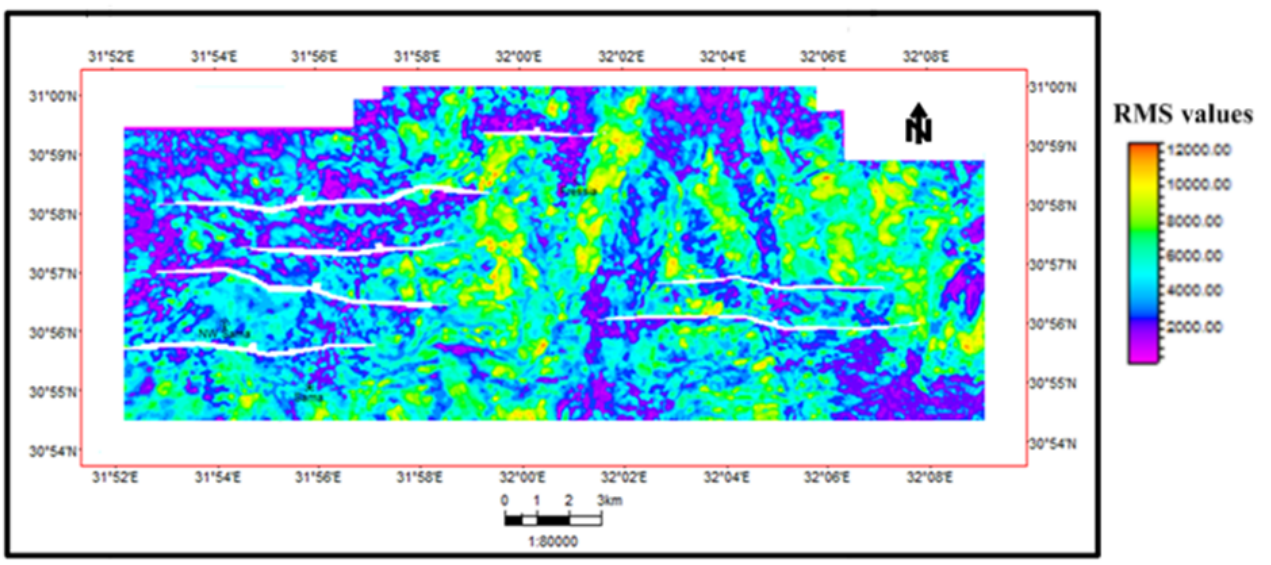

Fig. 13: The RMS attributes slice map above the Eocene boundary and below by a window of 40 $\mathrm{ms}$ in thickness showing the E-W fault trend.

The variance seismic volume is still the most useful attribute to use in the interpretation of this depositional system. The combination of variance interpretation with the original seismic data enables the interpreter to identify areas of several sinuous channel-levee complexes (the minor unit of submarine fans). This depositional feature has the potential to be a hydrocarbon reservoir (Wynn et al., 2007).

For this reason, the authors in their interpretation conduct several time slices along the variance attribute cube allowed a preliminary characterization of the depositional elements that belong to the target channel system. The variance time slice represented by Fig. (14) within the 500 (ms) TWT indicates that there is an overlapped sinus loops of high amplitude interrupted with low amplitude spots.

The shape of the feature avoiding the zero effect needed a vertical tracing through more greater TWT time other slices and claiming that the channel was originating deeper horizons or older age.

At time slice 750 (ms) in Fig. (15), the NW faults and the NE faults appeared. Figure (16a) illustrates the main geo-body of the channel and its cut off parts at time slice 1500 (ms). The coherence interpretation of this slice gave us an important information about the flow direction of the channel which is parallel to the sweep direction, Fig. (16b). The Hing zone E-W faults also present clearly here. When we go down more in depth (TWT), the feature is starting to disappear indicating that the channel was younger in age than the Oligocene and Eocene as shown in Figs. (17 and 18) respectively. The deep area is affected intensely by the effective tectonics.

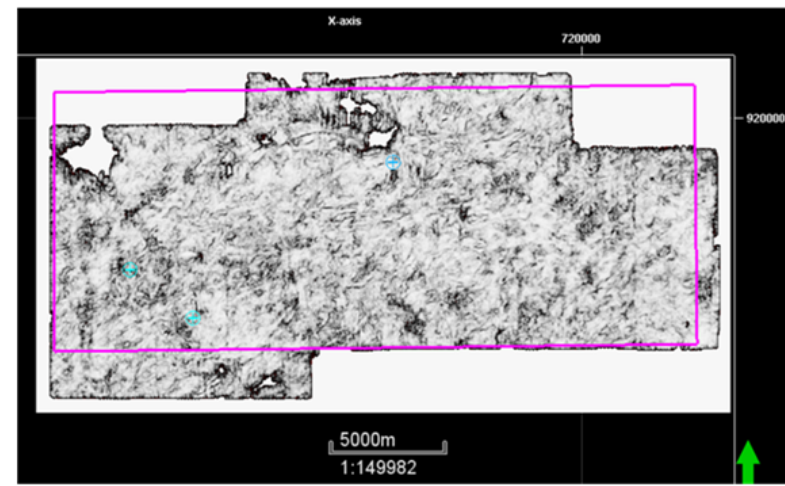

Fig. 14: Variance time slice within 500 (ms) TWT depicts the misleading zero effects.

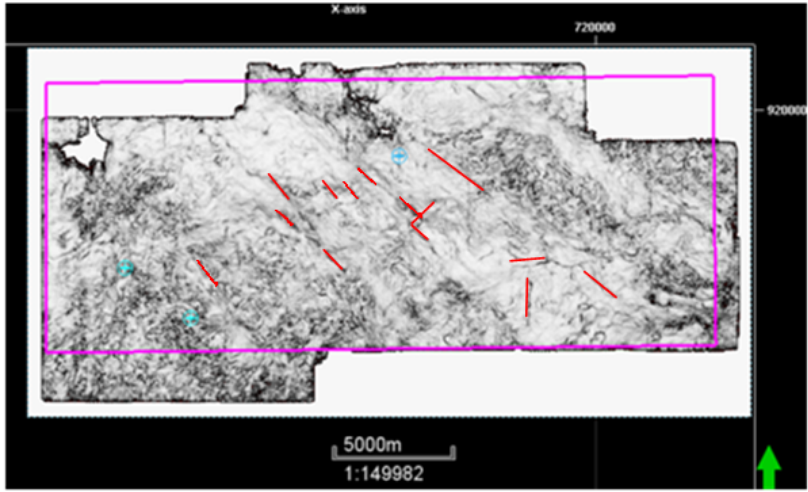

Fig. 15: Variance time slice within 750 (ms) TWT showing the existence of the fault treds.

\section{SUMMARY AND CONCLUSION}

The Nile Delta Basin is the most significant gas source province in Egypt and one of the most promising areas for future petroleum exploration in North-eastern Africa. In 2008 Dana Gas Egypt started an aggressive drilling campaign in West El Qantara block (WQ) onshore of the Nile Delta basin to test the attractive exploration potential; they achieved a remarkable success of gas discoveries. 
Enhancement of the 3D seismic interpretation by using seismic attributes

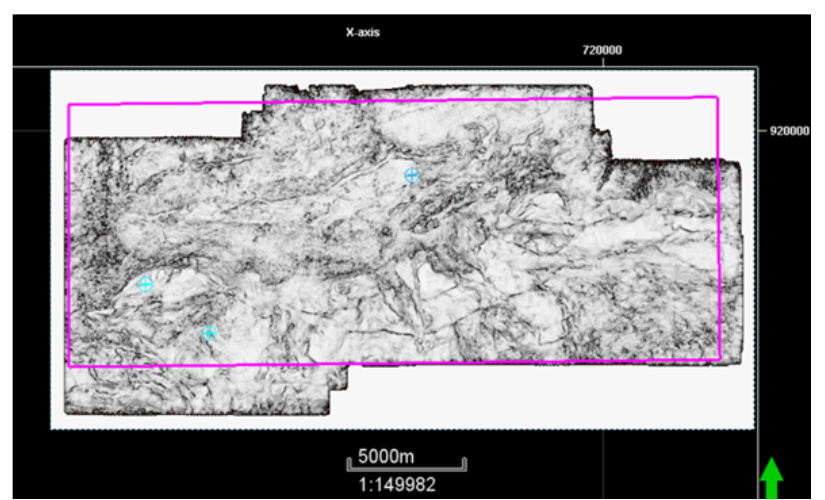

Fig. 16 a: Variance time slice within 1500 (ms) TWT depicts the main body of a channel.

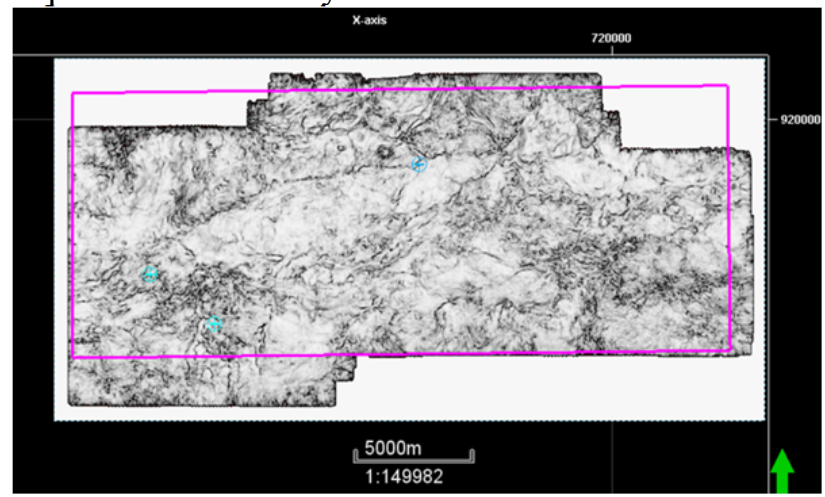

Fig. 17: Variance time slice within 2000 (ms) TWT showing pseudo fault traces.

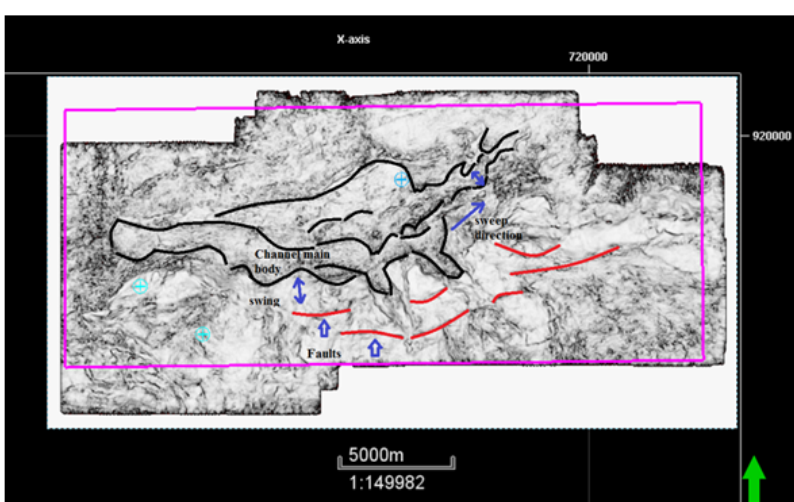

Fig. 16b: Coherence interpretation of the variance time slice $1500(\mathrm{~ms})$.

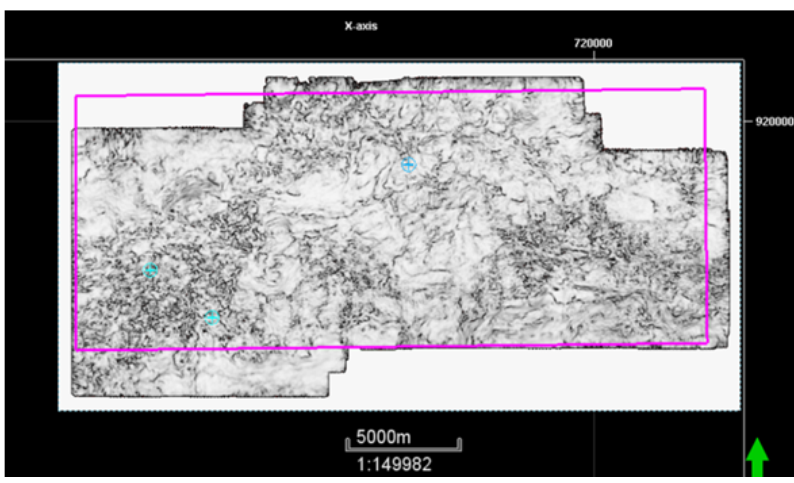

Fig. 18: Variance time slice within $2500(\mathrm{~ms})$ TWT showing a complete missing of the depositional feature with increasing depth

Nile Delta basin was the target of interest of too many scientists. (Said, 1990) and (Sestini, 1989) stated that the Nile Delta basin was affected by the complex evolution of the African, Eurasian and Arabian plates. The study area is located at the South West of El Qantara in the northern part the Nile Delta basin of Egypt. The study area located between latitudes $30^{\circ} 54^{\prime} 00^{\prime \prime}$ and $31^{\circ} 00^{\prime} 00^{\prime \prime} \mathrm{N}$ and longitudes $31^{\circ} 46^{\prime} 00^{\prime \prime}$ and $32^{\circ} 09^{\prime} 00^{\prime \prime} \mathrm{E}$.

The Nile Delta section composed of three sedimentary cycles:1) the Miocene cycle, whose base is rarely recorded in the delta region. It largely comprises non-marine to shallow marine deposits of the Sidi Salim, Qawasim and Abu Madi Formations. 2) Pliocene-Pleistocene cycle which includes the open marine Kafr El Sheikh Formation and the deltaic El Wastani, Mit Ghamr as well as Bilqas Formations. 3) Holocene cycle which comprises the top. Based on geophysical studies, (Sherief, 1972) reported that the depth of the basement rocks is more than $1800 \mathrm{~m}$ at the southern part of the Nile Delta and increases northward into more than $7600 \mathrm{~m}$.

The Nile Delta Basin is a gas and condensate province, with only small amounts of oil. Reservoirs in the Nile delta can be classified according to depth into three types. The first type is the shallow reservoirs (800$2700 \mathrm{~m}$ ); they are represented by high quality Pliocene reservoirs (Kafer El Sheikh and El Wastani formations). The second is the intermediate reservoirs $(2700-4000 \mathrm{~m})$; they are include Upper Miocene reservoirs of the Abu Madi and Qawasim formations and The Middle to Upper Miocene Sidi Salim Formation. The third type is the deep reservoirs $(4000-6500 \mathrm{~m})$; they are include the Lower to Middle Miocene Qantara Formation and the Oligocene Tineh Formation (EGAS, 2015).

The authors conducted a 3D seismic interpretaion in the study area deliniating the major structures and the stratigraphic features of five horizons namely from top to bottom (Late Pliocene, Middle Pliocene, Late Miocene, Oligocene, and Eocene). The tying between seismic volumes and well Sama-1 through the synthetic seismogram was achieved. The time maps of the five horizons and the velocity maps were 
El Motany, et al.

established. The structural depth maps were produced. Several seismic inline and crossline sections were interpreted covering the area.

The application of seismic attributes analyses were done to enhance the 3D interpretation and to add small features to the interpretation process. The RMS attribute maps were created for testing the ambiguous lithologic stack anomalies. Furthermore, the variance attributes were made to be used in the interpretation of the depositional system. The combination of variance interpretation with the original seismic data enables the interpreter to identify areas of several sinuous channel-levee complexes (the minor unit of submarine fans). This depositional feature has the potential to be a hydrocarbon reservoir (Wynn et al., 2007).

The interpretation of different time variance slices indicates the presence of a channel depositional feature on the top of Abu Madi Formation or near it. This channel with a sweep or directional flow NNE and NE-SW. This coincide with the depositional history models which was carried out on the area previously and add more details to them. The channel mainly of sand and can extend the reservoir for future development especially in the central part of the area and along the eastern part.

Finally, we can conclude that the application of the 3D seismic attributes are very important tools when they combined with the 3D seismic interpretation. They can characterize the reservoir by adding many structural and stratigraphic features which cannot be recognized or seen without these attribute analyses. The South West El Qantara in the Nile delta area is a promising area when it comes to the hydrocarbon exploration or development. We are recommending development future drilling in the central part of the current study area and in the eastern side too.

\section{ACKNOWLEDGEMENT}

The authors are indebted to both DANA GAS Company and the Egyptian General Petroleum Corporation (EGPC) for providing the raw seismic reflection data of the SW El Qantara field which were used in the the present 3D seismic study.

The authors appreciated the help of Mr. Hatem El-Ssayed, Helwan University, Cairo, Egypt and his technical tips in the 3D seismic interpretation.

\section{REFERENCES}

Adero, B., Masinde, A. and Osukuku, G. (2017): Using seismic attributes for reservoir characterization. Oil, Gas and Mines Africa, Exhibition and Conference (OGMA), Nairobi, Kenya, 5P.

Azevedo, L. (2009): Seismic Attributes in Hydrocarbon Reservoirs Characterization. M.Sc. thesis, Department of Geosciences, University of Aveiro, Portugal, 165P.

Badely, M.E. (1985): Practical seismic interpretation. International Human Resources Development Corporation, Boston, USA, 266P.

Brown, A.R. (1996): Seismic attributes and their classification. The Leading Edge, 15(10), 1090-1090.

Chopra, S., Marfurt, K.J. (2005): Seismic attributes: A historical perspective. Geophysics, 70(5), 3SO$28 \mathrm{SO}$.

EGAS (2015): Nile Delta Basin and Offshore North Sinai Concessions. Technical Report (1) of 8 exploration blocks. Egyptian Ministry of Petroleum and Mineral Resources, 9P.

El-Heiny, I. and Morsi, S. (1992): Stratigraphic correlation of Neogen sediments eastern Nile Delta and Gulf of Suez, EGPC, $11^{\text {th }}$ Petrol. Explor. and Prod. Conf., Cairo, 1, 166-193.

Khalf, A. (2016): Mud logging quality control and pore pressure prediction using geological and geophysical data in selected fields, Nile Delta, Egypt. PhD thesis in Geology, Faculty of Science, Mansoura Univ. ,112P.

Lindseth, R. O. (1979): Synthetic sonic logs: A process for stratigraphic interpretation. Geophysics. 44(1), $3-26$.

Said, R. (1990): The Geology of Egypt, Balkema, A.A., Rotterdam, Netherland, 743P.

Sestini G. (1976): Geomorphology of the Nile Delta. Nile Delta Sedimentology Seminar, Alexandria, Egypt, UNESCO/UNDP, 12-14. 
Enhancement of the 3D seismic interpretation by using seismic attributes

Sestini, G. (1989): Nile Delta depositional environments and geological history. In Pickering, K., and Whateley, T. (Eds.): Deltas sites and traps for fossil fuel. Geol. Soc. London Spec. Publ. Blackwell Scientific Publications, London. 41, 99-128.

Sestini, G., (1995): Egypt. In: Kulke, H. (Ed.): Regional Petroleum Geology of The World, Part II: Africa, America, Australia and Antarctica (Beiträge zur regionalen Geologie der Erde 22, Gebrüder Borntraeger Verlagsbuchhandlung, Stuttgart, Germany, 66-87.

Sherief, R. (1972): A geophysical study on the Nile Delta Area, for petroleum prospection, Ph.D. Thesis, Cairo University, Egypt, 204 P.

Sheriff, R. E. and Geldart, L. P. (1982): Exploration Seismology: History, Theory and Data Acquisition. Cambridge University Press, Cambridge, v. (2).

Taner, M. T. (2001): Seismic attributes, Canadian Society of Exploration Geophysicists Recorder, 48-56.

Tylern, M. (2015): Applications of 3D seismic attribute analysis workflows: A case study from Ness County, Kansas, USA. M. Sc. thesis, Department of Geology, Kansas State Univ., Kansas, USA, 50 P.

Wynn, R. B., Cronin, B. T. and Peakall, J. (2007): Sinuous deep-water channels: Genesis, geometry and architecture. Marine and Petroleum Geology, 24, $341-387$. 
El Motany, et al.

تحسين تفسير البيانات السيزميه ثلاثية الأبعاد باستخدام الخواص السيزميه في منطقة جنوب غرب القنطره في دلتا النيل ، مصر

أمبر المطعني'، عبد الناصر هلال 2 و كرم سمير إبراهيم 2

1. مستشار جيوفيزيائي، القاهره ، مصر.

2. قسم الجيوفيزياء ، كلية العلوم-جامعة عين شمس.

- الخلاصة

إن الهدف الأساسي من الدراسة الحاليه هو التعرف على المظاهر التركيبيه و الطبقيه للمصايد البتروليه باستخدام البيانات السيزميه ثلاثية الأبعاد في منطقة جنوب غرب القنطره في حوض دلتا النيل بمصر ـ الاستخدام التكاملي للخواص السيزميه (الإنحراف، متوسط مربع السرعات، استخراج السعه) أضاف معلومات مهمه للمظاهر الجيولوجيه والتغيرات الرسوبيه و التراكيب الدقيقه في منطقة الدراسه ومن ثم حسن من تحديد التجمعات الهيدروكربونيه. إن المضاهاه بين النماذج الخاصه بالمظاهر التركيبيه والمترسبه المستخرجه من البيانات السيزميه ثلاثية الأبعاد مع الوضع

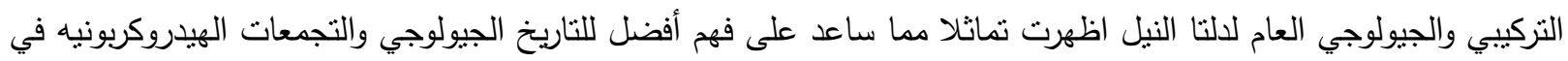
منطقة الدراسه. وهذا قد يستخدم كأداة في تطوير الانتاج الهيدروكربوني المستقبلي في المنطقه. 